\title{
Maya and WRB Soil Classification in Yucatan, Mexico: Differences and Similarities
}

\author{
Héctor Estrada-Medina, ${ }^{1}$ Francisco Bautista, ${ }^{2}$ Juan José María Jiménez-Osornio, ${ }^{1}$ \\ José Antonio González-Iturbe, ${ }^{3}$ and Wilian de Jesús Aguilar Cordero ${ }^{1}$ \\ ${ }^{1}$ Departamento de Manejo y Conservación de Recursos Naturales Tropicales (PROTROPICO), \\ Campus de Ciencias Biológicas y Agropecuarias (CCBA), Universidad Autónoma de Yucatán (UADY), \\ Km 15.5 Carretera Mérida - Xmatkuil, Mérida, Yucatán 97315, Mexico \\ ${ }^{2}$ Centro de Investigaciones en Geografía Ambiental (CIGA), Universidad Nacional Autónoma de México (UNAM), \\ Antigua Carretera a Pátzcuaro No. 8701, Col. Ex-Hacienda de San José de La Huerta, Morelia, Michoacán 58190, Mexico \\ ${ }^{3}$ Facultad de Arquitectura (UADY), Calle 50 S/N x 57 y 59 Ex-Convento de La Mejorada, Mérida, Yucatán 97000, Mexico
}

Correspondence should be addressed to Héctor Estrada-Medina; hector.estrada@uady.mx

Received 11 October 2013; Accepted 10 November 2013

Academic Editors: M. B. Adams and C. Martius

Copyright (c) 2013 Héctor Estrada-Medina et al. This is an open access article distributed under the Creative Commons Attribution License, which permits unrestricted use, distribution, and reproduction in any medium, provided the original work is properly cited.

Soils of the municipality of Hocabá, Yucatán, México, were identified according to both Mayan farmers' knowledge and the World Reference Base for Soil Resources (WRB). To identify Maya soil classes, field descriptions made by farmers and semistructured interviews were utilized. WRB soils were identified by describing soil profiles and analyzing samples in the laboratory. Mayan farmers identified soils based on topographic position and surface properties such as colour and amount of rock fragments and outcrops. Farmers distinguished two main groups of soils: K'ankab or soils of plains and Boxlu'um or soils of mounds. K'ankab is a group of red soils with two variants (K'ankab and Haylu'um), whereas Boxlu'um is a group of dark soils with five variants (Tsek'el, Ch'ich'lu'um, Chaltun, Puslu'um, and Chochol). Soils on the plains were identified as Leptosoils, Cambisols, and Luvisols. Soils identified in mounds were Leptosols and Calcisols. Many soils identified by farmers could be more than one WRB unit of soil and vice versa; in these cases no direct relationship between both classification systems was possible. Mayan and WRB soil types are complementary; they should be used together to improve regional soil classifications, help transference of agricultural technologies, and make soil management decisions.

\section{Introduction}

Local soil classification systems play an important role in many agricultural sites throughout the world but they have not considered to construct scientific classification systems [1]. Opportunities to use traditional systems to improve scientific soil classifications, mapping, and environmental impact monitoring are not fully exploited [2]. In countries like Mexico, indigenous soil knowledge of ancestral groups [3-7] need to be understood to facilitate planning, transmission, and implementation of new agricultural technologies $[3,8]$.

Local knowledge is restricted geographically, dynamic, collective, diachronic, and holistic; it is the product of a long observation history, analysis, and management of the natural resources, transmitted orally from generation to generation [9]. Traditional soil classification systems, created by the users, have a local importance and are based on properties easily affected by management [10]. This knowledge is enough to understand and manage the soil in a local way to solve short term specific problems $[2,11,12]$. On the other hand, scientific soil classification systems are based in measurable and observable soil characteristics defined in terms of diagnostic properties, materials, and horizons related to the soil morphology [13]. Traditional knowledge is being lost because these new regionally applied scientific schemes do not consider it. Incorporation of both types of knowledge into a more useful scheme requires the development of a 


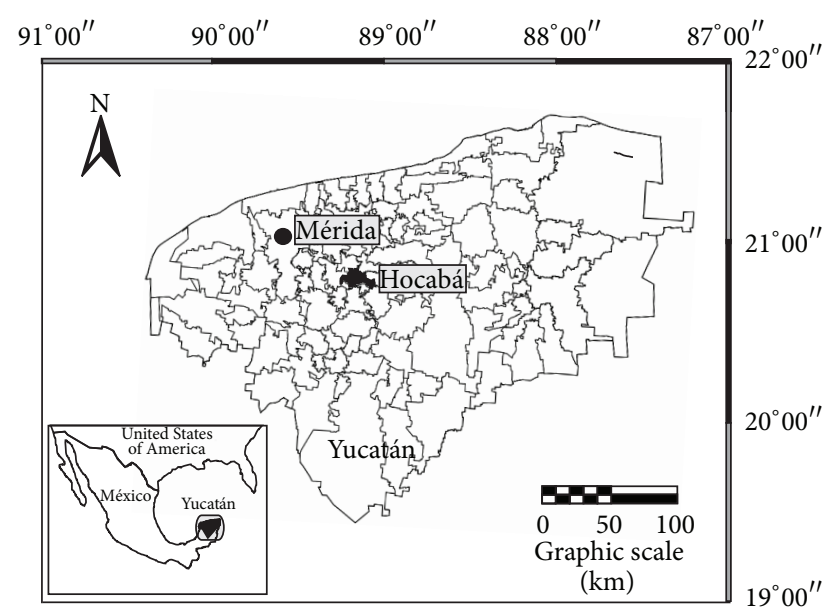

Figure 1: Study zone.

common language among farmers, extensionists, technicians, and researchers.

In Yucatán, farmers descended from the old Mayan culture still have a great quantity of knowledge about soils, which they continue using for their agricultural practices $[5,8,14]$; studies concerning this matter are descriptive and only a few have attempted to systematize this knowledge and relate it to scientific soil classification systems [15-17]. In this study the soils of the municipality of Hocabá, Yucatán, México, were identified according to the Mayan farmers' knowledge and the WRB system. The differences and similarities between the two systems were analyzed in order to identify the best correspondence between them.

\section{Materials and Methods}

2.1. Study Zone. The municipality of Hocabá is located in the central region of the state of Yucatan at $20^{\circ} 49^{\prime} \mathrm{N}$ and $89^{\circ} 15^{\prime} \mathrm{W}$ within the geomorphologic landscape defined by Lugo [18] as a "structural plain almost horizontal marginal to the coast" with up to $10 \mathrm{~m}$ of altitude (Figure 1). Hocabá occupies an area of $81.75 \mathrm{~km}^{2}$ that represents $0.18 \%$ of the state territory [19]. The climate is subhumid tropical with a summer rain season $\mathrm{Aw}_{1}\left(\mathrm{i}^{\prime}\right) \mathrm{g}[20,21]$. The dominant vegetation is low deciduous forest [22] and the main crops of the land are sisal (Agave fourcroydes Lem.) and corn [23]. Two geologic zones converge in this area: a 58 million years ago limestone zone, with fine grain silicated and scarce presence of fossils in the majority of the municipality, and a 13 to 25 million years ago limestone zone, in the southeast part of the municipality, with cream and brownish microcrystalline grey rocks with great amount of fossils [24]. Intercalated zones of plains and mounds compound the topography. Mounds reach diameters of 3 to $10 \mathrm{~m}$ and heights up to $3 \mathrm{~m}$; the plains usually have a diameter of 10 to $30 \mathrm{~m}$ [14].

Forty semistructured interviews with Mayan farmers were carried out in order to obtain information about the Mayan soil knowledge of the municipality of Hocabá. Interviewed farmers were "milperos" (farmers who grow
TABLE 1: Characterization of interviewed farmers from Hocabá, Yucatán, México.

\begin{tabular}{lccccc}
\hline \multicolumn{2}{c}{ Farmer age } & \multicolumn{2}{c}{ Years doing milpa } & \multicolumn{2}{c}{ Number of mecates* } \\
Range (years) & $n$ & Range & $n$ & Range & $N$ \\
\hline $20-29$ & 3 & $1-9$ & 6 & $1-9$ & 3 \\
$30-39$ & 1 & $10-19$ & 7 & $10-19$ & 6 \\
$40-49$ & 8 & $20-29$ & 6 & $20-29$ & 12 \\
$50-59$ & 7 & $30-39$ & 4 & $30-39$ & 6 \\
$60-69$ & 10 & $40-49$ & 4 & $40-49$ & 5 \\
$70-80$ & 8 & $50-59$ & 9 & $50-59$ & 3 \\
$>80$ & 3 & $>60$ & 4 & $>60$ & 5 \\
\hline
\end{tabular}

${ }^{*} 1$ mecate $=400 \mathrm{~m}^{2}$.

milpa-association of corn, bean, and pumpkin) because they are the ones who have more contact and experience using the soil resource. Interviews were conducted directly on the parcel of each farmer where they were asked to mention and show the types of soils they knew, their properties or ways to recognize them, and their abundance and distribution. Farmers were also asked about types of crops they prefer to grow on each kind of soil, type of management, fertilizing, main weeds, and typical problems. The only criterion to select a farmer to be interviewed was the occurrence of their parcel in any of the two main areas of corn production within the municipality [23]. Farmers that only spoke Maya were interviewed with the help of a translator. Based mainly on the predominant responses obtained during the interviews as well as the observations made on the field, the scheme of the Mayan soil classification for this area was built. Once the Mayan soils types were recognized, representative pits for each Mayan soil identified were excavated and profiles were described [25], sampled, analysed, and classified using the WRB classification system [13]. A comparative approach was used to establish similarities and differences between Mayan knowledge and WRB system.

\section{Results}

The 40 interviewed farmers (4\% of the milperos of the municipality) recognized 11 different classes of soils. Most of the interviewed farmers of the study area were older than 40 years, with variable experience on making milpa and worked an average area of 1 ha per year (Table 1). Farmers from 60 to 69 years old provided the majority of information about the recognition of the soils, identifying eight classes. Farmers of the three older ranges of age recognized all the types of soils found on the municipality (Table 2 ). There were only 2 out of 11 classes of soils recognized by all the farmers (Boxlu'um and $\left.K^{\prime} a n k a b\right)$; the other 9 classes were recognized only by $25 \%$ or less of the farmers. The soil properties that Mayan farmers considered to classify their soils are very easy to be observed, these properties included topographic position and colour followed by amount of rock fragments, outcrops, and water retention (Table 3 ).

Farmers also recognized differences between soils according to the crops they prefer to grow on each class of soil 
TABLE 2: Number of soils recognized by the interviewed farmers from Hocabá, Yucatán, México.

\begin{tabular}{|c|c|c|c|c|c|c|c|c|}
\hline \multirow{3}{*}{ Name } & \multicolumn{8}{|c|}{ Age range } \\
\hline & $20-29$ & $30-39$ & $40-49$ & $50-59$ & $60-69$ & $70-80$ & $>80$ & $\%$ \\
\hline & $n=3$ & $n=1$ & $n=8$ & $n=7$ & $n=10$ & $n=8$ & $n=3$ & $N=40$ \\
\hline K'ankab & 3 & 1 & 8 & 7 & 10 & 8 & 3 & 100 \\
\hline Boxlu'um & 3 & 1 & 8 & 7 & 10 & 8 & 3 & 100 \\
\hline Puslu’um & & & & 4 & 3 & 3 & & 25.0 \\
\hline Ch'ich'lu’um & 1 & & 1 & 2 & 1 & & & 12.5 \\
\hline Muluch buk'tun & & & 2 & & 2 & & 1 & 12.5 \\
\hline Ek'lu'um & 1 & & 1 & & 1 & & & 7.5 \\
\hline Chochol & & & & & & 1 & & 2.5 \\
\hline Tsek’el & & & & & & 1 & & 2.5 \\
\hline Chaltun & & & & & 1 & & & 2.5 \\
\hline Chaklu'um & & & & & 1 & & & 2.5 \\
\hline Haylu’um & & & & & & & 1 & 2.5 \\
\hline
\end{tabular}

TABLE 3: Characteristics of the Mayan soils of the municipality of Hocabá, Yucatán, México.

\begin{tabular}{|c|c|c|c|c|c|}
\hline \multirow{2}{*}{ Name } & \multicolumn{5}{|c|}{ Visual characteristics } \\
\hline & Soil color & Topographic position & Superficial rock fragments & Outcrops & Water retention \\
\hline K'ankab, Chaklu'um & Red & Only on plains & Low or none & Low or none & Good \\
\hline Haylu'um & $\begin{array}{c}\text { Brown or } \\
\text { reddish-brown (dark } \\
\text { colors) }\end{array}$ & Base of the mounds & $\begin{array}{l}\text { Low amount of fine } \\
\text { gravels or none }\end{array}$ & $\begin{array}{l}\text { Hard rock within first } \\
\qquad 10 \mathrm{~cm} .\end{array}$ & $\mathrm{Bad}$ \\
\hline Chichlu’um & Clear brown or black & $\begin{array}{l}\text { On the flat top of the } \\
\text { mounds }\end{array}$ & A lot of fine gravels & Low & Good \\
\hline Puslu'um & Black & Mounds & $\begin{array}{c}\text { Low amount of gravels or } \\
\text { none }\end{array}$ & $\begin{array}{l}\text { Hard rock within first } \\
\qquad 10 \mathrm{~cm} .\end{array}$ & Very bad \\
\hline Chochol & Black & Base of the mounds & Piles of cobbles & None & Good \\
\hline $\begin{array}{l}\text { Tsek'el, Yan yan } \\
\text { tunichi', Mulu'ch } \\
\text { buk'tun }\end{array}$ & Black & Mounds & $\begin{array}{l}\text { High in gravels, stones, } \\
\text { and cobbles }\end{array}$ & High & $\mathrm{Bad}$ \\
\hline Chaltun & Black & Mounds & Low or none & Very high & Bad \\
\hline
\end{tabular}

and the agronomic problems they perceive (Table 4). They do milpa in any type of soil without discriminating between mound or plain soils. Specifically, they usually prefer sowing varieties of local chilli (Capsicum spp.) in the mound soils called Ch'ich'lu'um. Similarly, vegetable crops and other great diversity of crops are usually sowed in the plain soils free of rock fragments and outcrops called K'ankab. Weeds develop quicker on plain soils because there are more seeds there than in the mound soils and they can germinate at any moment when conditions become favourable. Among the plants that are exclusive or develop quicker on mound soils are Chichibé (Sida acuta Burm.) and Sac kaatzim (Mimosa bahamensis Benth.), while on plain soils Sacchiu (Abutilon permolle (willd.) Sweet) and other grasses, Habin (Piscidia piscipula Sarg.), Tzalam (Lysiloma latisiliquum (L.) Benth), Tsotsk'ab (Mentzelia aspera L.), Kiintal (Desmodium purpureum (Mill.) Fawe), and Tajonal (Viguiera dentata (Cav.)) were also mentioned.

Farmers pointed out the following problems, remarking that they are present with different intensity in each soil class. Generally, mound soils have lower water retention and incidence of gophers, raccoons, and weeds than red soils. The sum of all these factors results, according to farmers, in low yields.

Farmers also use the type of rock associated with soils to classify them. Even more, farmers classify and use those different types of rocks according to their properties and use (Table 5). Farmers recognized five types of rocks; from those, two of them have relevant properties to agriculture, as they appear to have good water retention.

According to the WRB, soil units identified on the plains were Chromic Luvisols (LVcr), characterized by the presence of a Bt horizon and CEC $>24 \mathrm{cmol} \mathrm{kg}^{-1}$ through the whole profile; Epileptic Cambisols (lep-CM), Endoleptic Cambisols (len-CM), and Endoskeletic Cambisols (skn-CM) having a Bw horizon but varying in depth and amount of rock fragments; and Lithic Leptosols (li-LP), which are soils up to $10 \mathrm{~cm}$ depth (Table 6).

On the mounds, the soil groups were Leptosols (LP) and Calcisols (CL). Both are dark colored (chroma less than 3) and have high organic matter contents from 23 to $50 \%$ (Table 7 ). Both groups have minimal amounts of fine earth due to 
TABLE 4: Crops and agronomic problems of the soils of Hocabá, Yucatán, México.

\begin{tabular}{|c|c|c|}
\hline Maya soil name & Preferred crops* & Detected problems \\
\hline K'ankab & $\begin{array}{l}\text { Jamaica (Hibiscus sp.), macal (Xanthosoma } \\
\text { yucatanense), jicama (Pachyrhizus erosus), yuca } \\
\text { (Manihot esculenta), and sweet potato (Ipomoea } \\
\text { batatas). }\end{array}$ & $\begin{array}{l}\text { Weeds grow faster. Tuzas (Dasyprocta mexicana) } \\
\text { and raccoons (Procycon spp.) are more frequents. }\end{array}$ \\
\hline Haylu'um & $\begin{array}{l}\text { Maize (Zea mays), beans (Phaseolus spp., Vigna } \\
\text { spp.), and pumpkins (Cucurbita spp.). }\end{array}$ & As they are shallow soils, maize falls down easily. \\
\hline Ch'ich'lu’um & $\begin{array}{l}\text { Chili pepper (Capsicum spp.) and sometimes sweet } \\
\text { potato. }\end{array}$ & Tuzas (less frequent). \\
\hline Puslu'um & Maize, beans, and pumpkins & Shallow soils, low water retention. \\
\hline Chochol & None & $\begin{array}{l}\text { Little surface for planting (too many rock } \\
\text { fragments) }\end{array}$ \\
\hline $\begin{array}{l}\text { Tsek'el, Yan yan tunichi', } \\
\text { Mulu'ch buk'tun }\end{array}$ & Maize, beans, and pumpkins & $\begin{array}{l}\text { Little surface for planting (many rock fragments). } \\
\text { Presence of weeds. }\end{array}$ \\
\hline Chaltun & Maize, beans, and pumpkins & $\begin{array}{l}\text { Little surface for planting (too much rock). } \\
\text { Very shallow soils. }\end{array}$ \\
\hline
\end{tabular}

${ }^{*}$ Farmers do not have any preference to where to grow Sisal (Agave fourcroydes); they all agreed that the more rock fragments and outcrops in the soil the better the growth of Sisal.

TABLE 5: Types of rock and their characteristics according to the farmers of Hocabá, Yucatán, México.

\begin{tabular}{|c|c|c|c|}
\hline Maya name & Spanish name* & Use & Characteristics \\
\hline Saktunich o Sascab & Creta & To build roads & $\begin{array}{l}\text { It converts in powder and absorbs much } \\
\text { water }\end{array}$ \\
\hline Xuxtunich & Roca desgranable & $\begin{array}{l}\text { Like sandpaper to cleaning } \\
\text { animals, to complete } \\
\text { albarradas }\end{array}$ & $\begin{array}{l}\text { It breaks easily even by hand or when it is } \\
\text { burned and absorbs water }\end{array}$ \\
\hline Toktunich & Roca fracturable & To build albarradas & $\begin{array}{c}\text { Very hard, when it is buried is not broken } \\
\text { only turns black and does not absorb } \\
\text { water }\end{array}$ \\
\hline Sakalbox & Roca soluble & $\begin{array}{l}\text { To make hand grinders and } \\
\text { albarradas }\end{array}$ & $\begin{array}{l}\text { It is the hardest one and does not absorb } \\
\text { water }\end{array}$ \\
\hline Haysaltunich & Laja & $P i b^{* * *}$, to complete albarradas & Does not absorb water \\
\hline
\end{tabular}

${ }^{*}$ Only laja is a common name among farmers, the other 4 names were derived from observations of their properties; ${ }^{* *}$ Albarrada is a wall made of rocks; ${ }^{* * *}$ Pib means cooking in pits.

the high content of rock fragments. There are three different types of Leptosols: (1) Hyperskeletic Leptosol (LPhsk), having more than $80 \%$ by weight of rock fragments; (2) Nudilithic and Lithic Leptosol (LPli), having a depth less than 5 and $10 \mathrm{~cm}$, respectively, and; (3) Calcaric Humic Leptosol (LPca$\mathrm{hu}$ ), more than $10 \mathrm{~cm}$ in depth, high organic matter content, and calcium carbonate content less than $40 \%$. Two types of Calcisols were recognized (CL): (1) Epipetric Skeletic Calcisol (CLptpsk) and (2) Epileptic Skeletic Calcisol (CLlepsk) both of them differing in their depth.

\section{Discussion}

4.1. Soils Identification. In Hocabá, Yucatán, soil knowledge is being lost because there are less young people interested in making milpa, the main activity that relates farmers to soil. Whit each generation, fewer young people engage in this activity because most of them prefer a salaried work or studying. Moreover, most of the adults younger than 50 years old perform milpa in an intermittent way combining it with a salaried work [26]. The reduction of the available forest area to make milpa is also a factor in the abandonment of this activity [23]. All these causes are promoting the loss of the traditional soil knowledge; this is supported in this study by the observed relationship between farmers' age and number of soils they recognize. Loss of traditional soil knowledge is occurring similar to other parts of the world [2].

No classification system is static [12] and the Mayan soil classification is not an exception. Synonymies and differences in the descriptions given by the interviewed farmers confirmed this situation. In this study, four cases of possible synonymies were found: Puslu'um and Ch'ich'lu'um, K'ankab and Chaklu'um, Boxlu'um and Eklu'um, and Muluch buk'tun and Tsek'el. The first three cases are reported by $[8,15]$ as different soil classes.

Soil names and descriptions provided by the farmers were contrasted with those of previous works [15, 17]; all of them presented a similar number of soil classes and the descriptions were highly consistent, although some names varied (Table 8 ). In those works done at state and regional levels, only three additional soils were reported for the study area (Ya'axhom, Ak'alche, and Kacab), suggesting that Mayan 


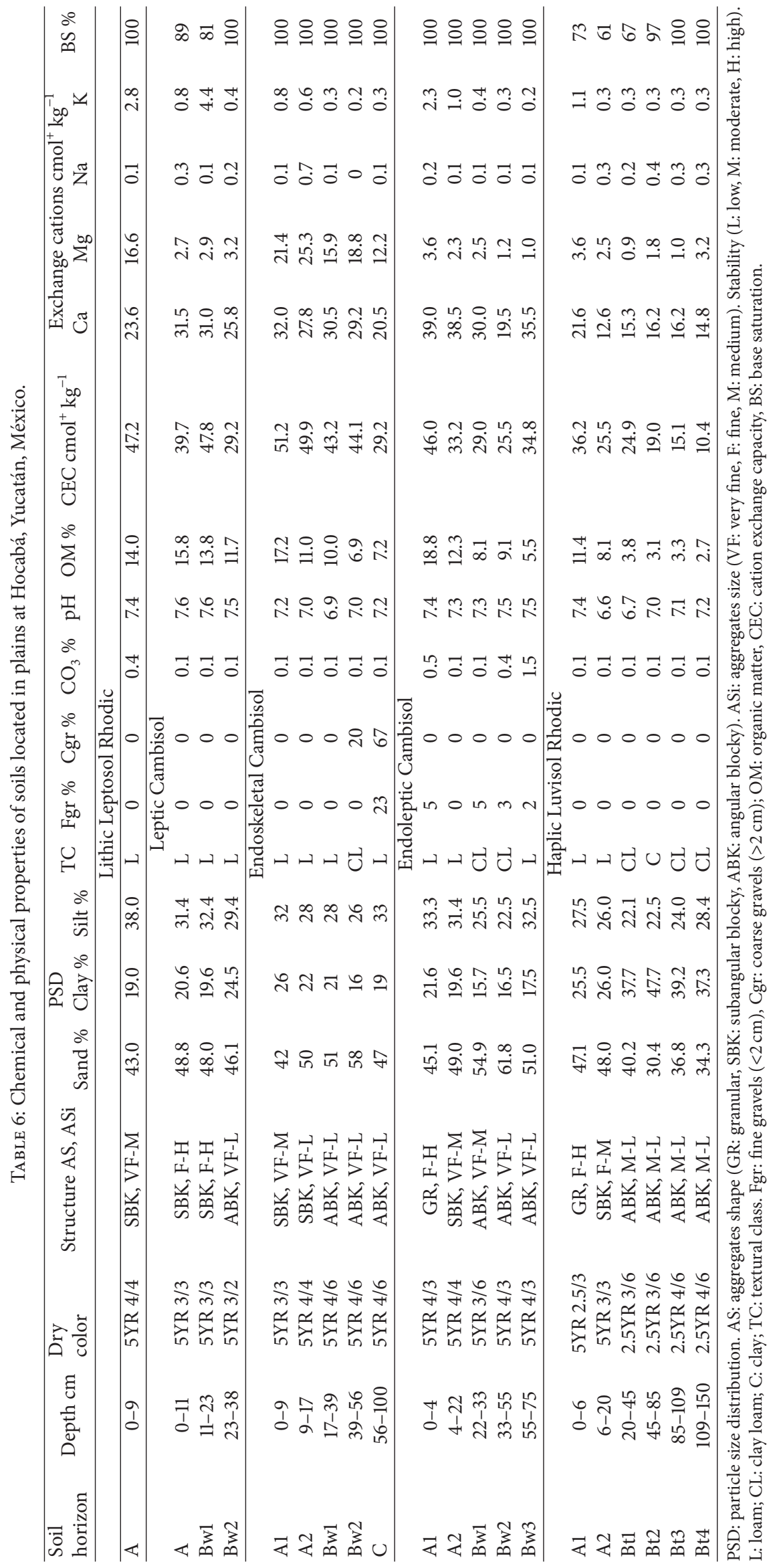




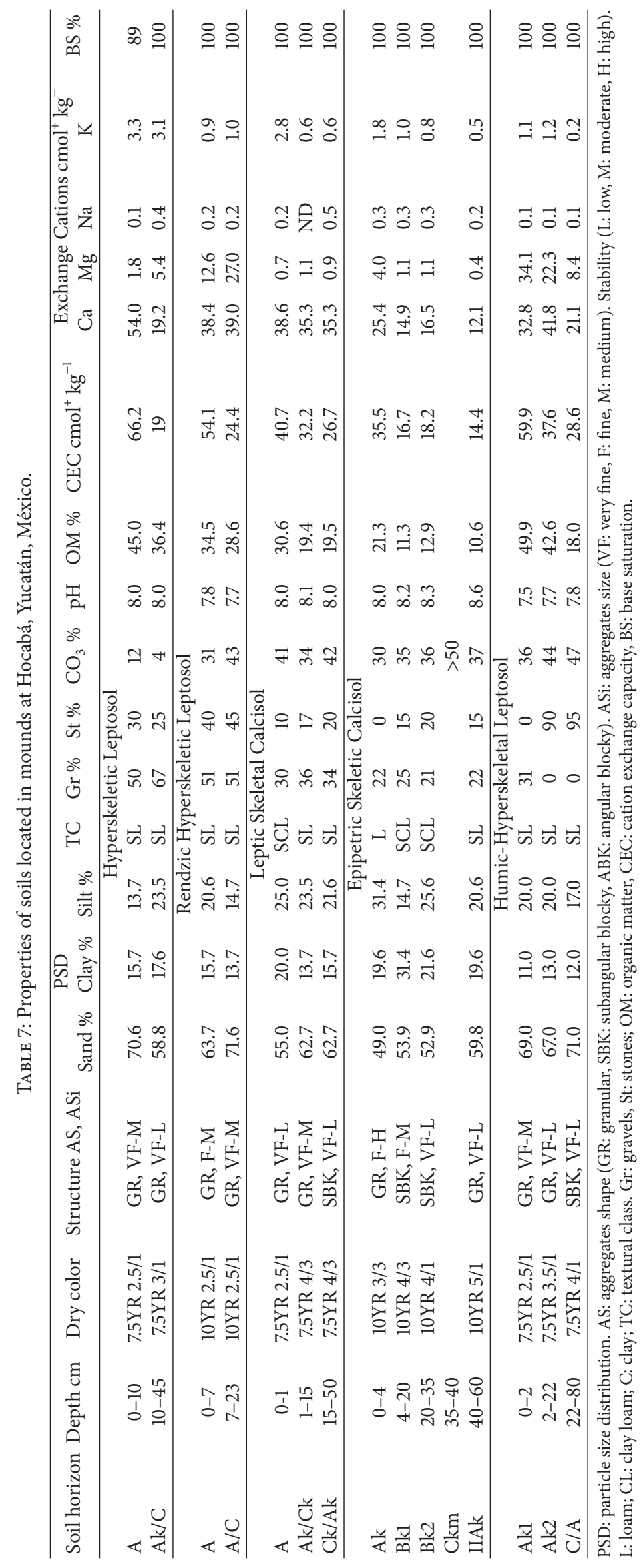


TABLE 8: Comparison between the descriptions of the soils found in the municipality of Hocabá, Yucatán, México, and those presented in others studies.

\begin{tabular}{|c|c|c|c|}
\hline Maya name* & Aguilera (1958) [31] & Duch $(1988,1991)[15,16]$ & This study \\
\hline K'ankab & Light red, deep soils & $\begin{array}{l}\text { Reddish brown color. Found it in plain } \\
\text { terrains }\end{array}$ & Red soil \\
\hline Boxlu'um & - & Black color & Black or dark soil \\
\hline Puslu’um & - & $\begin{array}{l}\text { Remarkable less amount of rock } \\
\text { fragments than Boxlu'um }\end{array}$ & $\begin{array}{l}\text { Black soil, soft, with no rock } \\
\text { fragments. It dries out quickly }\end{array}$ \\
\hline Ch'ich'lu'um & - & Very hard and gravel aggregates & Soil with abundant amount of gravels \\
\hline Muluch buk'tun & - & - & Soil with a lot of rock fragments \\
\hline Ek'lu'um & $\begin{array}{l}\text { Organic soil on calcareous rock } \\
\text { (Ek'lu'um Tsek'el) }\end{array}$ & - & Black soil \\
\hline Chochol & $\begin{array}{l}\text { Soil with calcareous rocks along } \\
\text { profile }\end{array}$ & $\begin{array}{l}\text { Soil with abundant rock fragments on } \\
\text { the surface }\end{array}$ & Soil under piled rock fragments \\
\hline Tsek'el & $\begin{array}{l}\text { Calcareous rock with a thin layer } \\
\text { of soil }\end{array}$ & $\begin{array}{l}\text { Shallow soil with abundant rock } \\
\text { fragments }\end{array}$ & Soil with abundant rock fragments \\
\hline Chaltun & Soil over laja rock & Soil with calcareous armour exposed & $\begin{array}{l}\text { Black shallow soil. } \\
\text { with cracked or holed rock }\end{array}$ \\
\hline Chaklu'um & - & Soil more red than K'ankab & Dark red soil \\
\hline Haylu'um & - & - & $\begin{array}{l}\text { Very shallow soil. Less than } 10 \mathrm{~cm} \\
\text { depth }\end{array}$ \\
\hline
\end{tabular}

*Writing of the Maya names is according to the Porrúa dictionary [32].

knowledge of soils is similar in the whole state. Typically, farmer classifications are highly variable or they have little consistency from region to region $[8,12,27]$; however, it seems that the Mayan soil knowledge is quite homogeneous, even at regional level [8]. This homogeneity can help to facilitate its systematization.

On the other hand, this apparent homogeneity could also indicate a loss of the soil knowledge. This statement is supported by the results of this work in which only two classes of soils were recognized by all the interviewed farmers (Boxlu'um and K'ankab) and these two terms were used to refer to the rest of the soils when they did not know them.

Most of the classification systems reflect the priorities of who propose them [28]. Characteristics that Mayan farmers use to classify soils are mainly visual and intimately related to their agricultural activities.

Farmers recognized colour differences among soils; however, it was observed that there are different tones that farmers do not consider as distinctive elements. A particular case is the Mayan term Box that means black or dark. Many farmers referred the soil called Chichlu'um that is usually light brown to dark brown as simply Boxlu'um. However, apparently this is related to the absence of a Mayan word to designate brown color, although some farmers used the Spanish term "achocolatado" (colored as chocolate) to refer to this colour. Another special case is the soil called K'ankab whose common translation is "yellow place at the bottom" in attention to subsuperficial soils horizons [8]. The Mayan word Chak means red; thus, Chaklu'um are red soils. These soils are darker than other red top soils such as K'ankab.

Soil depth was only an important characteristic for farmers to differentiate between shallow (soils $<10 \mathrm{~cm}$ ) and deep soils (soils $>10 \mathrm{~cm}$ ). Farmers recognized these soils empirically during sowing when they insert their sowing stick, by observation of aerial roots on maize plants, or when maize plants fall down due to the wind action because roots lack deep anchorage. Farmers affirmed that mound soils are not very deep but they pointed out that roots always find cracks in the rocks to continue growing. Shallow soils are called Haylu'um in both plains and mounds and correspond to Nudilithic Leptosols. Farmers judge the depth of K'ankab by its surface color, the darker the soil is the shallower it is, and the lighter the soil is the deeper it is. Bautista and Zinck [8] reported these differences in deepness for Kankab soils.

The microtopographic position, superficial amount of rock fragments, and outcrops are three characteristics that the farmers always consider together. We found five rock types with different uses and it is possible that they influence soil characteristics and soil genesis $[14,26]$. For example, soils called Chochol can only be found at the base of the mounds under stone accumulations (Hyperskeletic Leptosols), while soils designated Chaltun are almost always near the mounds but present bedrock very near to the surface (Nudilithic Leptosols).

Water retention is a characteristic that many farmers recognized but their comments relative to this property were inconsistent. For many farmers soils that do not retain water (they dried out first) were those on the mounds, while others assured that it was the soils on the plains. This disagreement can be due to the farmers not considering the variability in the amount of rock fragments or the depth of the soils as factors that determine the water retention. In fact, this characteristic was only relevant to recognize the soil called Puslu'um, which farmers consistently designated as the soil that dried out first.

Other studies have found that soil texture is an important property for local classifications $[11,29]$, but it seems that this 
is not the case of the Mayan classification, because none of their agricultural practices requires a direct physical contact with the deeper layers of soil.

4.2. Soils Uses. Preferences for growing crops were mainly linked to the more availability of workable surface for sowing in plain soils. Farmers like to grow most of their crops on the K'ankab soils, because the absence of rock fragments and outcrops makes field operations easier and quicker. The one clear exception is the soil called Ch'ich'lu'um, in which farmers prefer to sow peppers and sweet potato, arguing that they only grow well in that class of soil. It is possible that a nutritional reason exists to explain the best development of those crops in that class of soil, but this remains to be confirmed with soil fertility analyses.

Although some farmers said that with good rain the mound soils give better production, most of them assured that crops on mound soils as well as plain soils grow well if it has rained well and on time. On the other hand, when rain is not good, some farmers said that the mound soils produce higher yields while others argue that the plain soils do. The reason for these inconsistencies could be the depth of the soils and the amount of rock fragments and outcrops. Comparatively, shallow soils can store less water than deep soils, but amount of rocks and stones on mound soils help to conserve the humidity better than in shallow plain soils.

Soil water content is a property associated by farmers with the presence of weeds. In this regard, they said that they have many problems to control weeds because as soon as it rains, weeds appear in the soil. They also pointed out differences in weed composition and abundance between mound and plain soils. A farmer making milpa in the same place for five years in a row said that every year he had to use more herbicide and dedicate more hours to remove weeds than the earlier year.

In contrast to what the authors of $[16,17]$ found, the farmers interviewed in this study did not use any terms to refer to soil fertility. This is perhaps because these authors did their studies using a deeper anthropologic approach. The author of [16] developed the hierarchical classification of the soils of the Puuc region of the state of Yucatan and outlined a classification departed from a linguistic point of view, grouping the soil classes according to the meaning of the Mayan names as well as some management aspects. Such research is important to obtain information that may no longer exist among the contemporary inhabitants of a region.

\section{Comparison and Systematization}

Our results suggest that Mayan soils knowledge is given at three levels (Figure 2). In level one, topographic position mound (Muluch) or plain (K'ankabal). Mound soils are dark, generally black, grey, or brown, while plain soils are red to red-brown which makes a first division among soil classes resulting in a general designation for soils according to their color. Dark soils are designated as Box'luum and red soils as Kankab. The prefix Box means literally black but it is used to refer to all classes of dark colours. On the other hand, the prefix K'an means literally yellow but is used to designate light red soils on plains. Level two is almost exclusive for mound soils since in the plains the amount of rock fragments and outcrops are nearly absent. However, in some cases, red mound soils, having abundant amount of rock fragments and outcrops, were observed and recognized by farmers as Ch'ichK'ankab or Tsek'el-K'ankab. This was the only case where farmers used a compound name mixing two single names.

In level three, variations of soils from the second level were recognized according to their association with specific topographic position. Here, there were two subdivisions: (1) soil names ending with the Mayan word lu'um, which means soil, for example, Ch'ich'lu'um-soil with gravels(Hsk-LP) or Haylu'um-very shallow soil-(Nu-LP) and (2) soils that were designated according to the specific microtopographic positions on which they occur, for example, Chochol-soil under piled rock fragments-(Hsk-LP), Tsek'el-soil among rock fragments-(Nu-LP), Chaltun-soil between outcrops-(Nu-LP). At this level, soils in mounds were recognized as K'ankab, Haylu'um Ch'ich'lu'um, Tsek'el, Chaltun, Puslu'um, Chochol, and so on. In the case of the plain soils, farmers only recognized two variants: K'ankab and Hay'lu'um. In both cases when farmers were not sure of the specific name of the soil, they designate as Boxluu'm to all soils in mounds and K'ankab to all soils in plains.

Following this scheme, it can be seen that level one (mound soils and plain soils) is the most studied level so far $[5,14,15]$. It is in the second and third levels that research is needed. It is in those levels where the participation of the farmers is important in order to better understand each one of the elements of the landscape and topography that they recognize and use to identify soils.

Mayan soil types and WRB units cannot be directly related to each other because these systems share few diagnostic properties and assign them different relative importance [8]. Many soils identified by farmers relate with more than one WRB group of soil and vice versa; in these cases, no direct relationship between both classification systems is possible (Table 9).

People's understanding of soils constitutes a complex knowledge system, with some categories similar or complementary to those used by modern soil science $[8,30]$. For example, even though hierarchical levels of the WRB system are based on qualitative and quantitative data, they use qualifiers to distinguish soils at secondary levels. Some of those characteristics, that is, gravels or rock fragments percentage, are related to the Mayan approach. For instance, amount of rock fragments is a very important property for building hierarchal levels in the Mayan soil nomenclature (e.g., Chochol) as well as in the WRB classification at the qualifier level (e.g., Hyperskeletic and Skeletic Leptosols).

\section{Conclusions}

In Hocabá, Yucatán farmers distinguished two main groups of soils: K'ankab or soils of plains and Boxlu'um or soils of mounds. Kankab is a group of red soils with two variants (K'ankab and Haylu'um), whereas Boxlu'um is a group of dark soils with five variants (Tsek'el, Ch'ich'lu'um, Chaltun, Puslu'um, and Chochol). Soils on the plains were identified as Leptosols, Cambisols, Cambisols, and Luvisols. Soils 


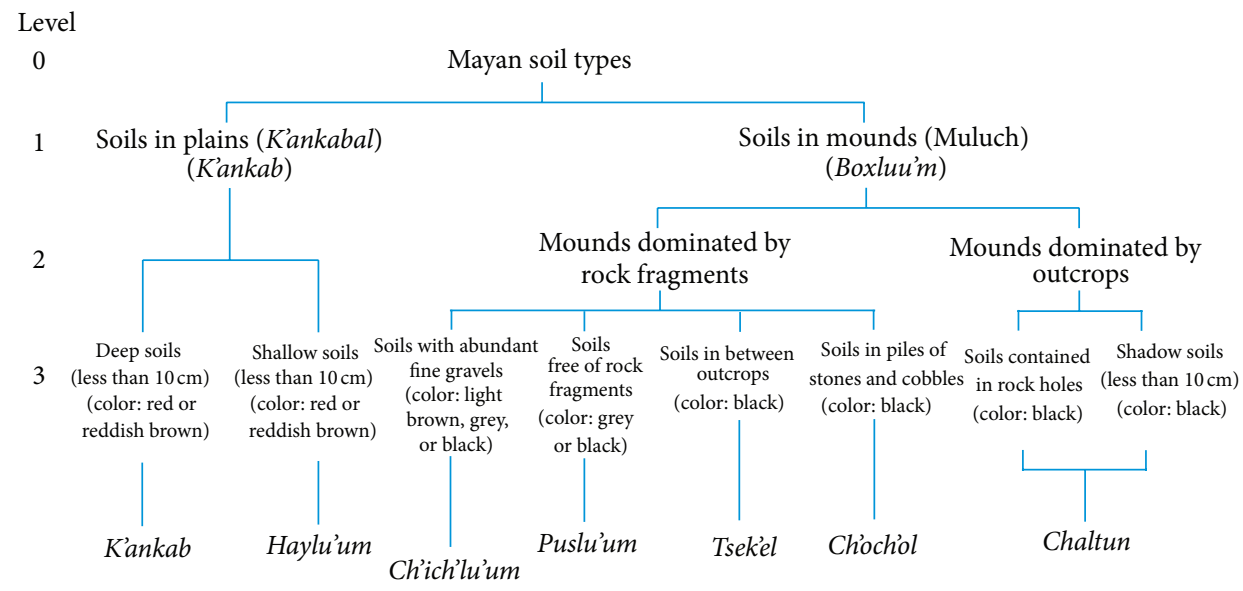

FIGURE 2: Mayan soil types in Hocabá, Yucatán.

TABLE 9: Relationship between WRB soil units and Mayan soil types.

\begin{tabular}{lccc}
\hline WRB soil group & Dominant kind of rock & Topographic position & Mayan soil class \\
\hline $\begin{array}{l}\text { Chromic Luvisols } \\
\text { Eutric Cambisols }\end{array}$ & Fracturable & Any part of the plains & K'ankab \\
$\begin{array}{l}\text { Mollic Leptosol } \\
\text { Nudilithic Leptosol }\end{array}$ & Fracturable & Base of the mounds & Haylu'um \\
Hyperskeletic Leptosol & & & Ch'ich'lu'um \\
Haplic Calcisol & Graintable and powderable & Flat tops of the mounds & Puslu'um \\
Hyperskeletic Leptosol & Fracturable and grainable & Top of the mounds & Ch'ich'lu'um \\
Petrocalcic Calcisol & Fracturable & Top of the mounds & Puslu'um \\
Nudilithic Leptosol & Fracturable & Sides of the mounds & Boxlu'um \\
Hyperskeletic Leptosol & Fracturable & Base of the mounds & Tsek'el \\
Rendzic Leptosol & Fracturable & Top of the mounds & Ch'och'ol \\
Nudilithic Leptosol & Soluble & Sides of the mounds & Boxlu'um \\
Nudilithic Leptosol & Soluble & Top of the mounds & Tsek'el \\
Lithic Leptosol & Fracturable & Sides of the mounds & Chaltun \\
Nudilithic Leptosol & Base of the mounds & Boxlu'um \\
\hline
\end{tabular}

identified in mounds were Leptosols and Calcisols. Mayan soil types and WRB groups are complementary; they should be used together in order to improve both soil classifications, to help transference of agricultural technologies, and make soil management decisions. Soil characteristics that should be considered for a local soil classification system are topographic position (plain or mound), colour, amount of rock fragments and outcrops, and soil depth or effective rooting depth.

\section{Acknowledgments}

Acknowledgments are due to the Science and Technology National Council (CONACyT) for the scholarship granted to the first author for his master degree studies; to CONACyT project: Base de datos para la península de Yucatán, incluyendo nomenclatura maya y FAO, Convenio: R31624$\mathrm{B}$; to the American Institute for Global Change Research (IAI), project: Biogeochemical cycles under land use change in the semiarid Americas; to Dr. Steve Gliessman, Dr. Robert Graham, and M.Sc. Arturo Caamal Maldonado for their comments and corrections to the paper; to Wendy Huchim and Miguel Huicab for their collaboration on some of the tables and figures. This paper is dedicated to the memory of my friend Mr. Pedro Canché farmer from Hocabá who with his wide knowledge of soils, roads, and people helped me as guide and Mayan-Spanish translator and in contacting other farmers.

\section{References}

[1] A. M. G. A. Winklerprins, "Local soil knowledge: a tool for sustainable land management," Society and Natural Resources, vol. 12, no. 2, pp. 151-161, 1999.

[2] P. V. Krasilnikov and J. A. Tabor, "Perspectives on utilitarian ethnopedology," Geoderma, vol. 111, no. 3-4, pp. 197-215, 2003.

[3] N. Barrera-Bassols and J. A. Zinck, "Ethnopedology: a worldwide view on the soil knowledge of local people," Geoderma, vol. 111, no. 3-4, pp. 171-195, 2003. 
[4] N. Barrera-Bassols, "Etnoedafología purhépecha," México Indígena, vol. 6, no. 24, pp. 47-52, 1988.

[5] F. Bautista, J. Jiménez, J. Navarro, A. Manu, and R. Lozano, "Microrelieve y color del suelo como propiedades de diagnóstico en Leptosoles cársticos," Terra, vol. 21, no. 1, pp. 1-12, 2003.

[6] B. J. Williams, “Aztec soil science," Boletín del Instituto de Geografía, vol. 7, pp. 115-120, 1975.

[7] B. J. Williams and C. A. Ortiz-Solorio, "Middle American folk soil taxonomy," Annals, Association of American Geographers, vol. 71, no. 3, pp. 335-358, 1981.

[8] F. Bautista and J. A. Zinck, "Construction of an Yucatec Maya soil classification and comparison with the WRB framework," Journal of Ethnobiology and Ethnomedicine, vol. 6, article 7, 2010.

[9] V. Toledo, "Indigenous knowledge on soils: an ethnoecological conceptualization," in Ethnopedology in A Worldwide Perspectives: An Annotated Bibliography, N. Barrera-Bassols and J. A. Zinck, Eds., International Institute for Aerospace Survey and Earth Science, Enschede, The Netherlands, 2000.

[10] A. J. Tabor, "Soil classification systems," in Soil of Arid Regions of the U.S. and Israel, 1997, http://cals.arizona.edu/oals/soils/ classifsystems.html.

[11] J. A. Sandor and L. Furbee, "Indigenous knowledge and classification of soils in the Andes of Southern Peru," Soil Science Society of America Journal, vol. 60, no. 5, pp. 1502-1512, 1996.

[12] A. J. Tabor, "Soil surveys and indigenous soil classification," Indigenous Knowledge and Development Monitor, vol. 1, no. 1, 1993.

[13] IUSS-ISRIC-FAO, “2006World reference base for soil resources 2006: A framework for international classification, correlation and communication," World Soil Resour Report 103, FAO, Rome, Italy.

[14] F. Bautista, H. Estrada-Medina, J. Jiménez-Osornio, and J. González-Iturbe, "Relación entre relieve y suelos en zonas cársticas," Terra, vol. 22, no. 3, pp. 243-254, 2004.

[15] G. J. Duch, La conformación territorial del estado de YucatánLos componentes del medio físico, Centro Regional de la Península de Yucatán CRUPY, Universidad Autónoma de Chapingo, México, Mexico, 1988.

[16] G. J. Duch, Fisiografía del estado de Yucatán-su relación con la agricultura, Centro Regional de la Península de Yucatán CRUPY, Universidad Autónoma de Chapingo, México, Mexico, 1991.

[17] P. N. Dunning, "Soils and vegetation," in Lords of the Hills: Ancient Maya Settement in the Puuc Region, Yucatán, México, vol. 15 of Monographs in World Archaeology, Prehistory Press, Madison, Wis, USA, 1992.

[18] J. Lugo, "Geomorfología," in Atlas de Procesos Territoriales de Yucatán, P. P. Chico, Ed., Universidad Autónoma de Yucatán, Yucatán, México, 1999.

[19] Gobierno Constitucional del Estado de Yucatán, "Programa de desarrollo regional de la zona Henequenera de Yucatán 19921994," México, 1992.

[20] INEGI, “Anuario estadístico del estado de Yucatán," Gobierno del estado de Yucatán, 1995.

[21] R. Orellana, "Evaluación Climática (Climatología de la Península de Yucatán)," in Atlas de Procesos Territoriales de Yucatán, A. García de Fuentes, C. Y. Ordóñez, and P. Chico Ponce de León, Eds., pp. 162-182, Facultad de Arquitectura, Universidad Autónoma de Yucatán, Mérida, Mexico, 2000.
[22] S. J. Flores and C. I. Espejel, “Tipos de vegetación de la península de Yucatán,” Fascículo 3, Sostenibilidad Maya. Universidad Autónoma de Yucatán, México, Mexico, 1994.

[23] L. Cano, Cambio del uso del suelo en el municipio de Hocabá, Yucatán, México [Tesis de maestría en Manejo y Conservación de Recursos Naturales Tropicales], Facultad de Medicina Veterinaria y Zootecnia, Universidad Autónoma de Yucatán, 2000.

[24] INEGI, "Instituto Nacional de Estadística, Geografía e Informática," Carta Geológica 1:250000, Secretaría de Programación y Presupuesto, México, Mexico, 1983.

[25] C. Siebe, R. Janh, and K. Stahr, "Manual para la descripción y evaluación ecológica de suelos en el campo.," Publicación Especial 4, Sociedad Mexicana de la Ciencia del Suelo, A. C. Edo. de México, México, Mexico, 1996.

[26] F. Bautista, J. Garcia, and A. Mizrahi, "Diagnóstico campesino de la situación agrícola en Hocabá, Yucatán," Terra Latinoamericana, vol. 23, no. 4, 2005.

[27] E. Habarurema and K. G. Steiner, "Soil suitability classification by farmers in southern Rwanda," Geoderma, vol. 75, no. 1-2, pp. 75-87, 1997.

[28] M. Corbeels, A. Shiferaw, and M. Haile, "Farmers' knowledge of soil fertility and local managament strategies in Tigray, Ethiopia," Managing Africa's Soils 10, IIED, London, UK, 2000.

[29] L. Pool-Novelo, E. Cervantes-Trejo, and S. Mesa-Díaz, "La clasificación Tsotsil de soils en el paisaje cárstico de la subregión San Cristobal de las casas, Chiapas, México," Terra, vol. 9, no. 1, pp. 11-23, 1991.

[30] N. Barrera-Bassols and A. J. Zinck, Ethnopedology in a Worldwide Perspectives: An Annotated Bibliography, International Institute for Aerospace Survey and Earth Science, Enschede, The Netherlands, 2000.

[31] N. Aguilera Herrera, "Suelos," in Los recursos naturales del Sureste y su aprovechamiento, E. Beltrán, Ed., Instituto Mexicano de Recursos Naturales Renovables, México City, Mexico, 1958.

[32] Porrúa, Dicccionario Maya, Editorial Porrúa, México, Mexico, 2 edition, 1991. 

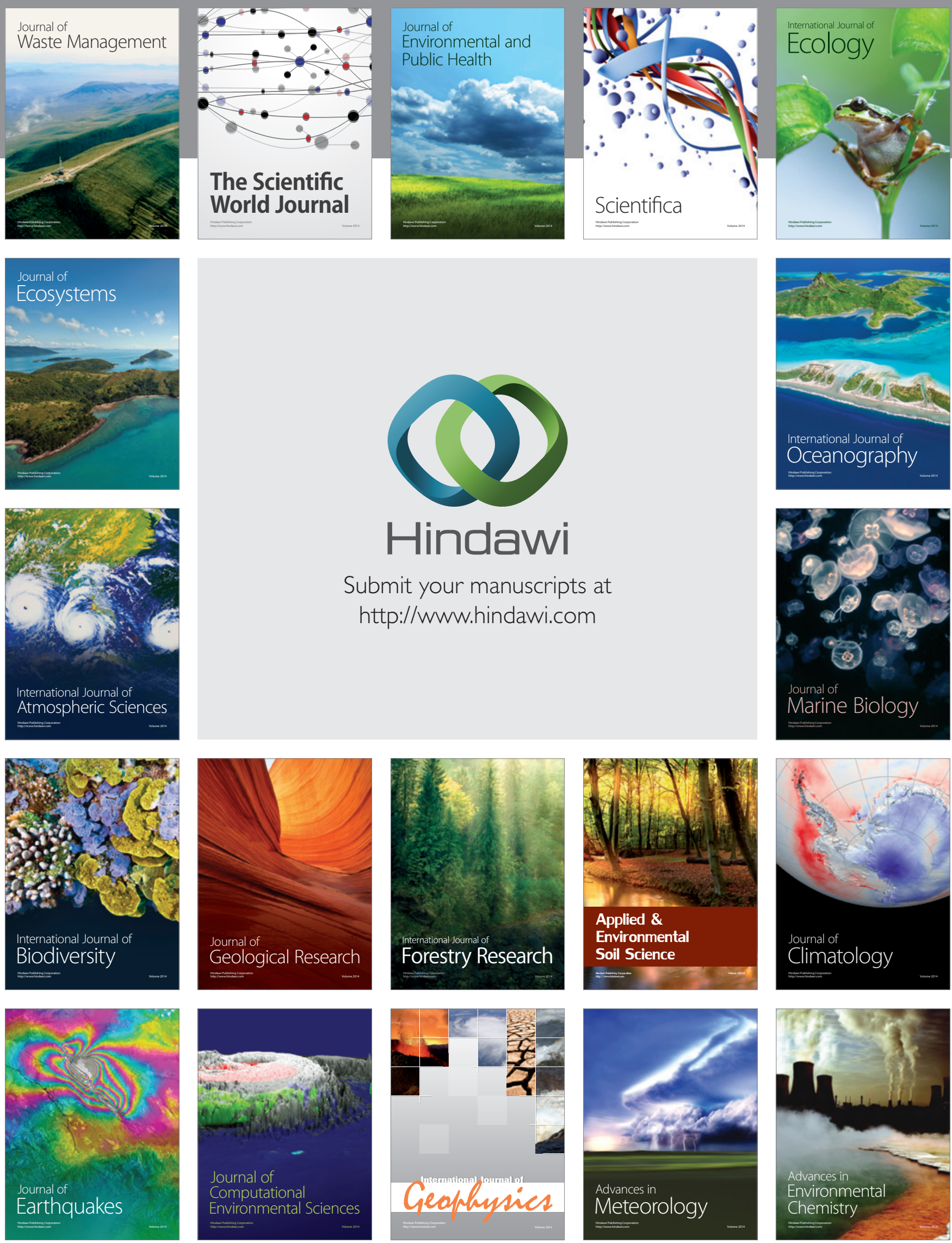